\title{
Juvenile European anchovy otolith microstructure
}

\author{
PABLO CERMEÑO ${ }^{1,3}$, BEATRIZ MORALES-NIN ${ }^{2}$ and ANDRÉS URIARTE ${ }^{3}$ \\ ${ }^{1}$ Blas de Otero, no 18, 5 izd. 48014 Bilbao. Bizkaia. Spain. E-mail: cermeno@euskalnet.net \\ ${ }^{2}$ IMEDEA (CSIC/UIB), Miquel Marqués 21, 07190 Esporles, Illes Balears, Spain. \\ ${ }^{3}$ Fundación AZTI, Herrera Kaia z/g, 20110 Pasaia, Gipuzkoa, Spain.
}

\begin{abstract}
SUMMARY: Juvenile European anchovy (Engraulis encrasicolus) has a complex incremental growth pattern that was studied using scanning electron microscope (SEM) and optical microscope observations. Daily increments were identified and related to rhythmic growth patterns while double-band structures were identified as one increment. The causes of these growth patterns are discussed.
\end{abstract}

Keywords: anchovy, Engraulis encrasicolus, sagitta, SEM.

RESUMEN: MicRoESTRUCTURA EN LOS OTOLITOS DE LA ANCHOA EUROPEA. - Los juveniles de anchoa europea (Engraulis encrasicolus) presentan un patrón complejo de crecimiento diario que ha sido analizado usando un microscopio electrónico de barrido (SEM) junto a observaciones con el microscopio óptico. Se identificaron los incrementos diarios relacionándolos con patrones de crecimiento rítmicos mientras los dobles incrementos, en forma de bandas, se identificaron como formadas por un solo incremento. Se discuten las causas de este patrón de crecimiento.

Palabras clave: anchoa, Engraulis encrasicolus, SEM.

\section{INTRODUCTION}

European anchovy (Engraulis encrasicolus) is an important species in the Bay of Biscay, both from an ecological and socio-economic point of view (Uriarte et al., 1996). The main characteristics of this small pelagic species are a short life span, seasonal migrations, high growth rates, early maturity (at 1 year old), long spawning period and schooling behaviour. Daily growth increment (DGI) formation in otoliths has been demonstrated for juvenile and adult European anchovy (Cermeño et al., 2003). This allows the age composition and growth rate, two fundamental tools for fisheries management, of this small pelagic fish to be determined.

However, determining the age of European anchovy using DGI is complicated due to the likely presence of sub-daily increments, as described in larvae of Engraulis japonicus (Tsuji and Aoyama, 1984) and in Engraulis encrasicolus (Palomera et al., 1989). The presence of doubly wide rhythmic growth patterns in the central zone of otoliths (whiter and darker bands) and groups of multiple increments are evidence of this. We tried two optical interpretation methods: In the first one, called Group Band Reading (GBR), the reader counts every repetitive cyclic set of growth bands or groups of microincrements as one (usually 2 but occasionally more), assuming that they are sub-daily marks. The second method, called Individual Mark Reading (IMR), takes into consideration every clear increment independently from its appearance.

This led us to analyze the microstructure of the otoliths using SEM to discern the multiple marks observed in the otoliths by identifying rhythmic growth patterns. 
TABLE 1. - Characteristics of the five zones in the sagitta otolith of European anchovy $(n=102)$.

\begin{tabular}{|c|c|c|c|c|c|}
\hline & \multirow{2}{*}{$\begin{array}{c}\text { Distance } \\
\text { to core }(\mu \mathrm{m})\end{array}$} & \multicolumn{3}{|c|}{ Width of increments $(\mu \mathrm{m})$} & \multirow[b]{2}{*}{ Description } \\
\hline & & $\mathrm{SD}$ & GBR & IMR & \\
\hline Zone I & 0 to 21.7 & \pm 3.36 & 0.9 to 2 & 0.9 to 2 & \multirow{5}{*}{$\begin{array}{l}\text { Typical larval core, rthymic and regular increments. } \\
\text { First subdaily increments appear, easly to discriminate. } \\
\text { Pattern of growth shows clear bands of alternant translucency. } \\
\text { These structures do not dissapear in any case. } \\
\text { Organic matter desposited. Increments become regular, decreasing } \\
\text { towards the edge. Subdaily increments are less evidents. } \\
\text { Continously decreasing. }\end{array}$} \\
\hline Zone II & 22.7 to 82.1 & \pm 17.4 & 3 to 7 & 3 to 6 & \\
\hline Zone III & 82.4 to 700.3 & \pm 99.89 & 7 to 17 & 6 to 13 & \\
\hline Zone IV & 700.3 to 1189.2 & \pm 80.9 & 9 to 13 & 9 to 13 & \\
\hline Zone V & 1189 to edge & - & 5 to 9 & 5 to 9 & \\
\hline
\end{tabular}

\section{MATERIAL AND METHODS}

The scanning electron microscope (SEM) reveals the topographic structure of surfaces. Thus, etched otoliths show incremental growth based on the relative differences in the organic matrix and aragonite microcrystals of the continuous and discontinuous units of the daily growth increments (Pannella, 1971; Brothers et al., 1976; Mugiya, 1977; MoralesNin, 1987). The otolith microstructure has been used to describe otolith growth properties (Irie, 1955; Campana, 1999; Morales-Nin, 2000) and discern if the optically observed structures correspond to daily or sub-daily rhythms, based on their microstructural architecture.

Juvenile European anchovy were captured in the Bay of Biscay from 1 to 16 September 1999 (JUVESU cruise 1999, Uriarte et al. 2001). Otoliths were extracted, cleaned and stored dry. For SEM observation sagittal sections were obtained from 15 sagittae (anchovy average standard length 6.01 $\pm 2.07 \mathrm{~cm}$ ), using standard methods (Morales-Nin and Panfili, 2002). The otolith sectioned surface was ultra polished using decreasing grain alumina paste to remove all surface scratches. The polishing process was controlled frequently under the microscope. After cleaning, the section was etched to reveal the ultrastructure using diluted $\mathrm{HCl}(1 \%, \mathrm{pH}$ 2.0-5.0), for $15 \mathrm{sec}$. The samples were affixed to
SEM stubs with double-sided tape. The surface was sputter coated with gold (100 Angstroms) before SEM observation using a Hitachi S-3500 N and backscatter electron mode.

\section{RESULTS}

Under the SEM the anchovy otoliths showed a low contrast between their different components (Fig. 2a). Although different etching times and EDTA were tested, the preparations did not improve (Fig. 2b). In most preparations dark areas appeared as a result of electron absorption (Fig. 1a, b arrow). These areas were probably due to the presence of insoluble organic material from the otolith matrix (Campana, 1999; de Pontual and Geffen, 2002). The aragonite crystals, a component of most otoliths (Degens et al., 1969), were small (Fig. 2c, d) and showed up in the otolith marginal area, which is the common radial growth perpendicular to the external otolith surface. They had a poorly developed prismatic structure as described for other fishes (Morales-Nin, 1986a). The otolith core (Fig. 3a) showed several faint increments (mean 8) before wider increments were laid down. These increments had a narrow and clear discontinuous unit (Fig. 3a black arrow). The organic material observed in the otoliths was also present in the core (Fig. 3a, white

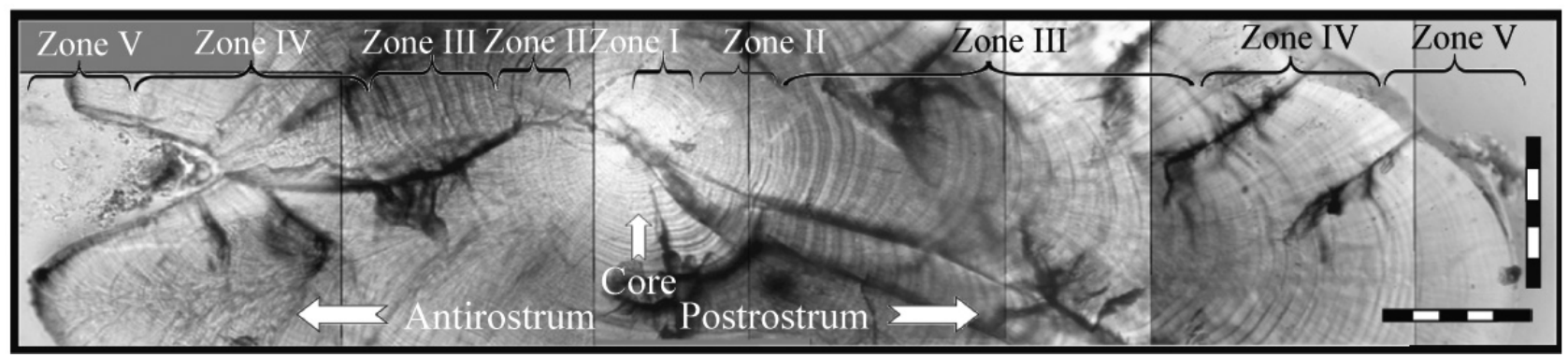

FIG. 1. - Optical micrograph of a Saggital section in a right saggita otolith showing the different zones and aspects of the increments (x10). (Bar $50 \mu \mathrm{m}$.) 

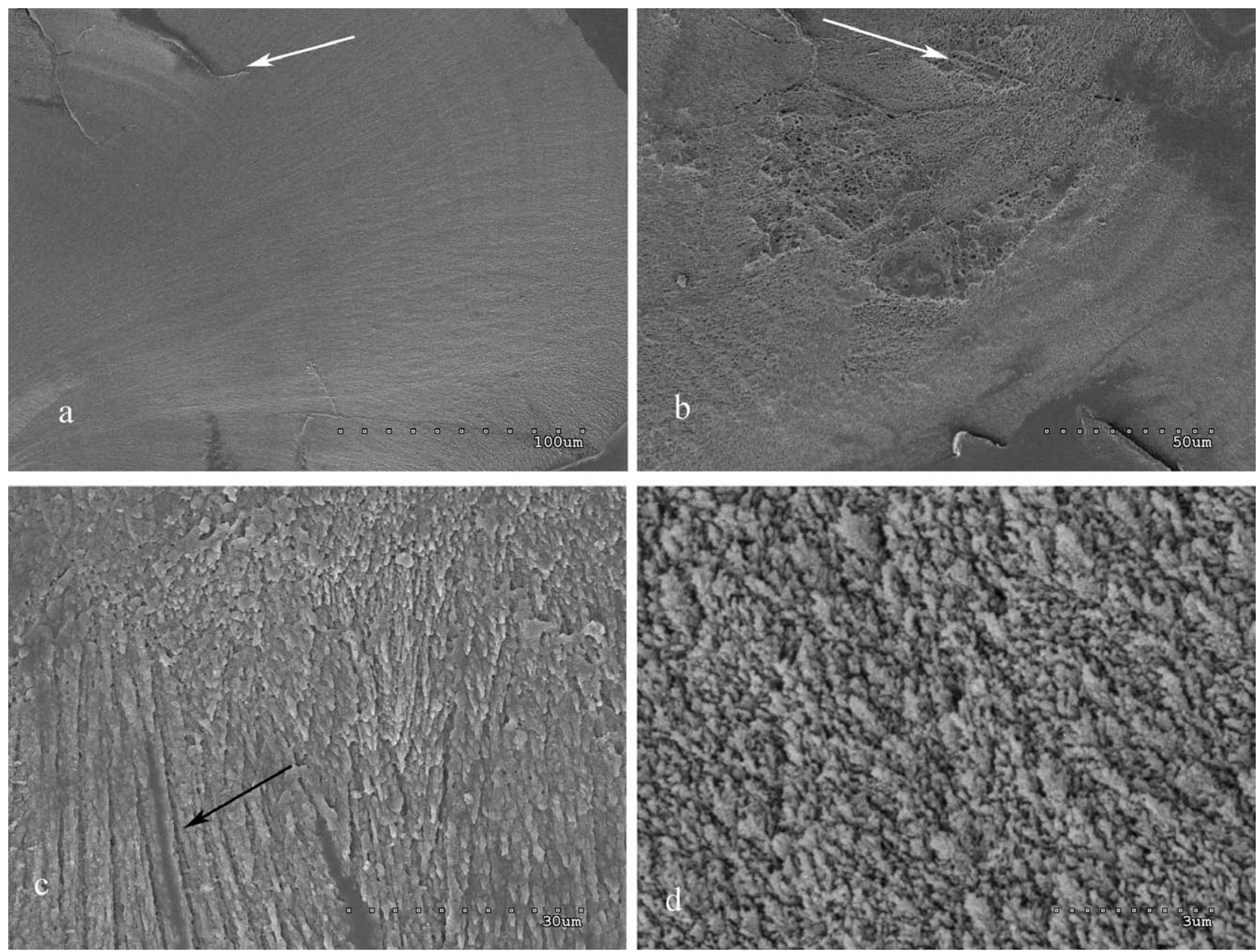

FIG. 2. - Scanning electron micrograph showing anchovy otolith microstructure. a) Smooth surface showing the poor definition of the daily growth increments. b) Over-etched surface showing that the increments were not revealed better with longer etching periods. a, b) White arrows: electron absorbing material, probably organic otolith matrix. c) Aragonite crystals with prismatic growth on the otolith edge (black arrow). d) Detail of the aragonite crystals in the otolith central area. Scale bar: a: $100 \mu \mathrm{m}, \mathrm{b}: 50 \mu \mathrm{m}, \mathrm{c}: 30 \mu \mathrm{m}, \mathrm{d}: 3 \mu \mathrm{m}$.

arrow). In general the contrast between the continuous and discontinuous units of the increments (Morales-Nin, 1987), which appeared respectively as ridges and valleys, was very poor (Fig. 3a, b). The incremental units appear as a bright narrow ridge, which probably has a more compact structure and is acid-resistant (Fig. 3b, arrows). The discontinuous units were very wide in Zone III (Fig. 3c, d) with small discontinuities inside.

The growth zones described using optical microscopy (Table 1 and Fig. 1) are also evident in the otolith microstructure. The core (Zone I) appears as a homogeneous circular structure with a diameter of c. $22 \mu \mathrm{m}$ (Fig. 3a) surrounded by a weak discontinuity and progressively thicker growth increments (Fig. 3b) ranging from 2 to $7 \mu \mathrm{m}$ (Table 1).

The number of increments from the core to the beginning of the diffuse increments is c. 23 increments (Zone II), which suggests that they might cor- respond to the beginning of metamorphosis (Palomera, 1989). The wide increments (ranging between 7 and $17 \mu \mathrm{m}$ ) (Zone III) appear limited by a brighter line which is contiguous to the discontinuous unit. This suggests that some hypermineralization occurred before the discontinuity was laid down (Fig. 3a, b, c). The area of wide increments reaches up to a radius of c. $700 \mu \mathrm{m}$, followed by progressively thinner increments in the marginal area.

\section{DISCUSSION}

Otoliths are composed of $\mathrm{CaCO}_{3}$ crystallized in aragonite form in an organic template formed by soluble and water insoluble collagen-like proteins (Degens et al., 1969; Morales-Nin, 1986b; Campana, 1999, and references cited herein). The microstructure of the anchovy otolith as revealed by 

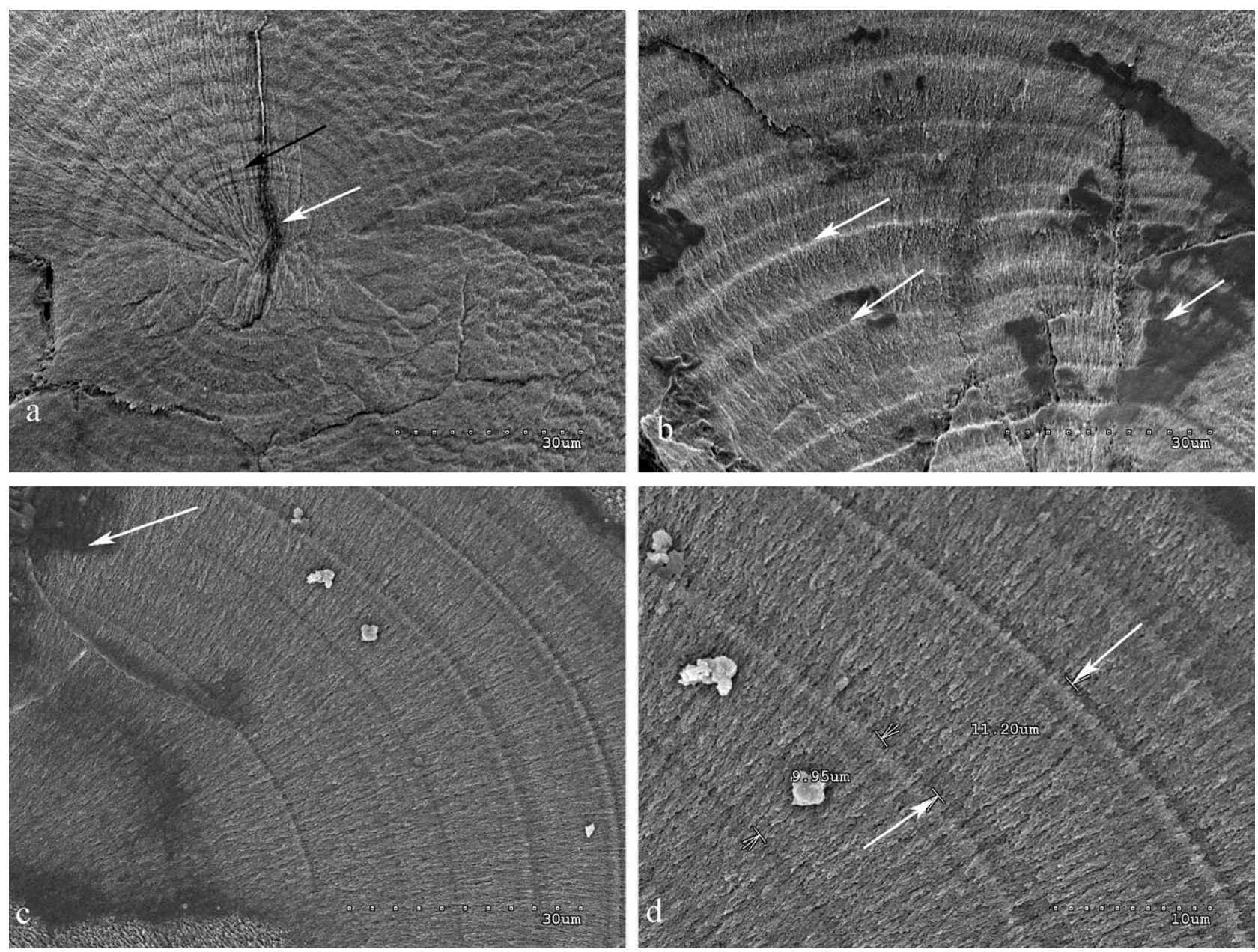

FIG. 3. - Scanning electron micrograph showing anchovy otolith microstructure. a) Central area showing the primordium and the first growth increments. Black arrow first clear discontinuous unit. b) Wide increments (corresponding to Zone II) with a thin ridge forming the continuous unit (black arrow) and wide discontinuous units (valleys). a, b, c) White arrows: electron absorbing material, probably organic otolith matrix. c) Growth increments in Zone III with small differences between the continuous and discontinuous units. d) Detail of c) with the increments indicated by arrows. Scale bar: a, b, c: $30 \mu \mathrm{m}, \mathrm{d}: 10 \mu \mathrm{m}$.

acid etching, showed a relatively uniform demineralization, which suggests that these otoliths are poorly mineralized and rich in organic matrix, probably with a low density. The organic matrix seems to be very uniformly distributed, although in the central area it is probably more abundant and forms some major discontinuities. The major discontinuity crossing the otolith core may be related to an organic frame although more detailed studies with techniques that conserve the matrix are needed to confirm this finding.

The uniform protein probably corresponds to a high continuous growth rate metabolism and stable environmental conditions during the initial life phases related to spawning grounds (Motos, 1996). This is probably the case, since Palomera (1991) showed that anchovy larvae in the Mediterranean Sea have very limited diurnal vertical migrations, and stay mostly above the thermocline. In addition, juvenile anchovy in the Bay of Biscay in September 1998 and 1999 (such as the ones analyzed in the current paper) were reported to stay above the thermocline all day (Uriarte et al., 2001). A similar lack of contrast in the increments was described for larval anchovy in the Mediterranean (Palomera et al., 1988).

The zones described at a macrostructural level are also evident under the SEM. In Zone III, the increments are wide and may correspond to high growth rates during the metamorphosis process, while some variation in the accretion rate appears to have occurred in Zone IV. A thin hypermineralized layer is laid down before the discontinuity, which suggests first a decrease in the protein accretion and afterwards a decrease in the mineral accretion. Similar structures at a macrostructural level have 
been described in other species (Morales-Nin, 2000) which correspond to daily growth rhythms.

The growth patterns described by SEM coincide with the observations using light microscopy. Due to the high-resolution power of the SEM, the wide increments are confirmed as a single unit. Thus, the possible presence of thin increments below the detection power of light microscopy is discarded. This makes band growth readings (GBR) the most reliable age determination procedure. Although some more detailed studies on the density and organic content of anchovy otoliths may be required to better understand their growth patterns, the information provided is the first detailed description of anchovy otolith microstructure.

\section{ACKNOWLEDGEMENTS}

We especially thank Mr. J.M. Fortuño (CMIMA) for his help in the SEM observations and also the two referees for their critical and useful comments on the manuscript.

\section{REFERENCES}

Brothers, E.B., C.P. Mathews and R. Lasker. - 1976. Daily growth increments in otoliths from larval and adult fishes. Fish. Bull., 74: $1-8$.

Campana, S. E. - 1992. Measurement and interpretation of the microstructure of fish otoliths. In: D.K. Stevenson and S. E. Campana (eds.), Otolith microstructure examination and analysis, pp. 59-71. Can. Spec. Publ. Fish. Aquat. Sci. ,117.

Campana, S.E. - 1999. Chemistry and composition of fish otoliths: pathways, mechanisms and applications. Mar. Ecol. Prog. Ser. 188: 263-297.

Cermeño, P., A. Uriarte, A. Martínez de Murguía and B. Morales-Nin. - 2003. Validation of daily increment formation in otoliths of juvenile and adult European anchovy. J. Fish. Biol., 62: 679-691.

Degens, E.T., W.G. Deuser and R.L. Haedrich. - 1969. Molecular structure and composition of fish otoliths. Mar. Biol., 2: 105-113.

de Pontual, H. and A. Geffen. - 2002. VII Otolith Microchemistry. In: J. Panfili, H. Troadec, H. de Pontual, P.J. Wright (eds.), Manual of Schlerochronology in Fishes, pp. 245-302. IFRE-
MER-IRD, Brest, France.

Irie, T. -1955 . The crystal texture of the otolith of a marine teleost Pseudosciaena. J. Fac. Fish. Anim. Husb. Hiroshima Univ., 1: $1-13$.

Morales-Nin, B. - 1986a. Structure and composition of otoliths of cape hake Merluccius capensis. S. Afr. J. mar. Sci., 4: 3-10.

Morales-Nin, B. - 1986b. Chemical composition of the otoliths of the sea bass (Dicentrarchus labrax, Linnaeus 1758) (Pisces, Serranidae). Cybium, 10: 115-120.

Morales-Nin, B. - 1987. Ultraestructure of the organic and inorganic constituents of the otoliths of the sea bass. In: R.C. Summerfelt and G.E. Hall (eds.), Age and Growth of Fish, pp. 331-343. Iowa State University Press, Ames Iowa USA.

Morales-Nin, B. - 2000. Review of the growth regulation processes of otolith daily increment formation. Fish. Res., 46: 53-67.

Morales-Nin, B. and J. Panfili. - 2002. VIII. Preparation and observation techniques. Observation. In: J. Panfili, H. Troadec, H. de Pontual, P.J. Wright (eds.), Manual of Schlerochronology in Fishes., pp. 358-369. IFREMER-IRD, Brest, France.

Motos, L. - 1996. Reproductive biology and fecundity of the Bay of Biscay anchovy population (Engraulis encrasicolus L.). Sci. Mar., 60 (Suppl. 2): 195-207.

Mugiya, Y. - 1977. Effect of acetazolamide on the otolith growth of gold fish. Bull. Jpn. Soc. Sci. Fish., 43: 1053-1058.

Palomera, I., B. Morales-Nin and J. Lleonart. - 1988. Larval growth of anchovy (Engraulis encrasicolus L. 1758) in the northeast Mediterranean. Mar. Biol., 99: 283-291.

Palomera, I. - 1989. Primeras fases del desarrollo de la anchoa (Engraulis encrasicolus) en la costa Catalana. Ph. D. thesis, Univ. Barcelona.

Palomera I. - 1991. Vertical distribution of eggs and larvae of Engraulis encrasicolus in stratified waters of the western Mediterranean. Mar. Biol., 111: 37-44.

Pannella, G. - 1971. Fish otoliths: daily growth layers and periodical patterns. Science, 173: 1124-1127.

Tsuji, S. and T. Aoyama. - 1984. Daily growth increments in otoliths of Japanese Anchovy larvae Engraulis japonica. Bull. Jap. Soc. Fish. Oceanogr., 50(7): 1105-1108.

Uriarte, A., P. Prouzet and B. Villamor. - 1996. Bay of Biscay and Ibero atlantic anchovy populations and their fisheries. Sci. Mar., 60(Suppl.2): 237-255.

Uriarte, A., Y. Sagarminaga, C. Scalabrin, V. Valencia, P. Cermeño, E. de Miguel, J.A. Gomez Sánchez and M. Jimenez. - 2001. Ecology of anchovy juveniles in the Bay of Biscay 4 months after peak spawning: Do they form part of the plankton?. ICES CM 2001/W:20. 1-45.

Wright, P.J., J. Panfili, B. Morales-Nin and A.J. Geffen. - 2002. II.Types of calcified structures. A. Otoliths. In: J. Panfili, H. Troadec, H. de Pontual, P.J. Wright (eds.), Manual of Schlerochronology in Fishes, 31-57. IFREMER-IRD, Brest, France.

Zhang, Z. and N.W. Runham. - 1992. Otolith microstructure pattern in Oreochromis niloticus (L.). J. Fish Biol, 40: 325-332.

Scient ed:. I. Palomera

Received January 10, 2005. Accepted February 21, 2006.

Published online September 5, 2006. 
